\title{
THE NEMASTOMATIDAE AND TROGULIDAE OF THE UNITED STATES.-II.
}

\author{
BY NATHAN BANKS, SEA CLIFF, N. Y.
}

\section{NEMASTOMATIDAE.}

The Nemastomatidae are readily divided into two well marked sub-families, which, according to some authors, should rank as families. They are separated as follows :-

Mandibles longer than the body.

Mandibles shorter than the body. Ischyropsalinae.

Nemastominae.

One species of Ischyropsalinae has been described from the United States by Simon as a new genus, Taracus packardi. Another species appears to belong to the same genus or very near it.

$\begin{array}{lllll}\text { Body smooth } & \cdot & . & . & T . p a c k a r d i . \\ \text { Body spiny } & \cdot & \cdot & \cdot & \text { T. spinosa } \\ \text { Taracus }\end{array}$

Taracus spinosa n. sp. Length, $2.1 \mathrm{~mm}$.; width, I.3 mm.; femur II, $2.2 \mathrm{~mm}$. Color pale yellowish, the claws of the mandibles reddish brown. Cephalothorax smooth; eye tubercle smooth, with two projections on each anterior side, each projection with a stiff bristle at tip; a short distance behind the eye tubercle is a strong and prominent median spine, at each side of which there is an oblique row of tubercles, with bristles at their tips. The entire dorsum, venter and coxae are closely covered with projections, each with a stiff black hair at the tip, those on the dorsum are curved. The legs, mandibles and palpi, except the terminal joints, are also covered with these bristles, which, however, are not situated on tubercles, except some on the mandibles. Palpi a little longer than the mandibles; fifth joint not one-half so long as the fourth, both with many short hairs. Fourth pair of legs wanting, second pair longest. It differs somewhat from the characters of the genus Taracus, in that the eye tubercle is not longer than wide.

California.

Of the Nemastominae we have two genera.

Fourth joint of palpi much thickened.

Phlegmacera.

Fourth joint of palpi scarcely thickened.

Nemastoma.

Phlegmacera Packard, must certainly be a Nemastomid and not a Phalangid as claimed by Packard [Cave memoir] ; no claw is mentioned or figured at the tip of the palpi, and the last joint is shorter than the penultimate. Two species are known to me which may be distinguished thus:-

A pair of prominent erect spines on the anterior part of the abdomen. P.occidentalis.

No such spines..$\quad$. $P$. cavicoleus.

Phlegmacera occidentalis, $\mathrm{n}$. sp. Length, $2.4 \mathrm{~mm}$. Color pale, with a large brown spot on the cephalothorax, the eye tubercle black; there is also a larger brown spot on the front part of the abdominal dorsum, widest behind, and within which are four median pale spots; tip of abdomen brown; venter 
pale, sutures margined with brown; coxae pale, with brownish bristles, palpi grayish with the tips of the second and third joints brownish; legs brownish, the trochanters pale, base and a ring near tip of femora, tips of the patellae and tibiae whitish, also a few white spots on the tarsi and metatarsi. The basal joint of the mandibles of the male is much prolonged above, the tip curving forward and bearing short black hairs. The eye tubercle is more prominent than in $P$. cavicoleus. The basal segment of the abdomen bears a row of spines, the median pair being much the largest; the next four segments have each a pair of humps crowned with stiff hairs. Third joint of palpi about equal to the fourth, the last joint more swollen than in $P$. cavicoleus. The palpi, as a whole, shorter than in that species.

Washington State (Trevor Kincaid).

Phlegmacera cavicoleus Pack. (Sabacon spinosus Weed, Amer. nat. June, I893).

Described from Bat Cave, Kentucky (Packard) and New Hampshire (Weed). I have collected at Ithaca, N. Y., under rotten logs in a deep gorge, what I take to be the same species. The female agrees with Packard's description and figure; the male has the fourth joint of the palpi less enlarged than in the female, the basal joint of the mandibles is prolonged upward in a horn, and there are stiff bristles on the abdominal ridges.

Nemastoma crassipalpis Koch (Arachniden aus Sibirien und Novaja Semlja) belongs to this genus.

Of Nemastoma there are three species.

Fourth joint of palpi less than twice as long as the fifth. . . . $N$. inops.

Fourth joint of palpi twice as long as the fifth.

Dorsum with some spines. $N$. modesta.

Dorsum without spines. $N$. troglodytes.
Nemastoma inops Pack. Bat Cave, Kentucky.

Nemastoma troglodytes Pack. Clinton's Cave, Utah.

Nemastoma modesta $\mathrm{n}$. sp. Length, 1.2 $\mathrm{mm}$.; gravid female, $2 \mathrm{~mm}$. The color of the dorsum is dark red-brown; the femora, patellae, and tibiae of the legs brownish, the other parts of appendages yellowish. The dorsum is granulated; the eye tubercle quite wide, and the eyes look upward; from each side of the hind margin of the eye tubercle there extends toward the posterior angles of the dorsal shield a curved row of peculiar tubercles, which have their summits enlarged, lengthened and flattened; at about the region where the cephalothorax and abdomen are united there is a curved transverse row of these tubercles, connecting the two longitudinal rows; this connecting row has, behind, two short branch rows of a few tubercles; behind these short rows are two diverging rows of four curved spines. The abdominal segments behind the dorsal shield are usually crowded together, but in the gravid female they are widely separated with a snow-white connecting membrane. The hard parts of the venter are red-brown, the stigmata black, all granulated and furnished with bristles. The trochanters are yellow, somewhat globular and with bristles; the other joints of the legs have fine hairs and a few bristles. The femora are small at base, gradually enlarging toward the tip; patellae same; tibiae more equal, the metatarsi with parallel sides. Second pair of legs longest. First joint of the palpi is small at base and larger near the tip, the second much longer, the third a little longer than the second, the fourth a little shorter than the third, the fifth about one-third the length of the fourth; all with bristles, most numerous on joints four and five.

California and Washington State (Trevor Kincaid). Evidently not uncommon. 

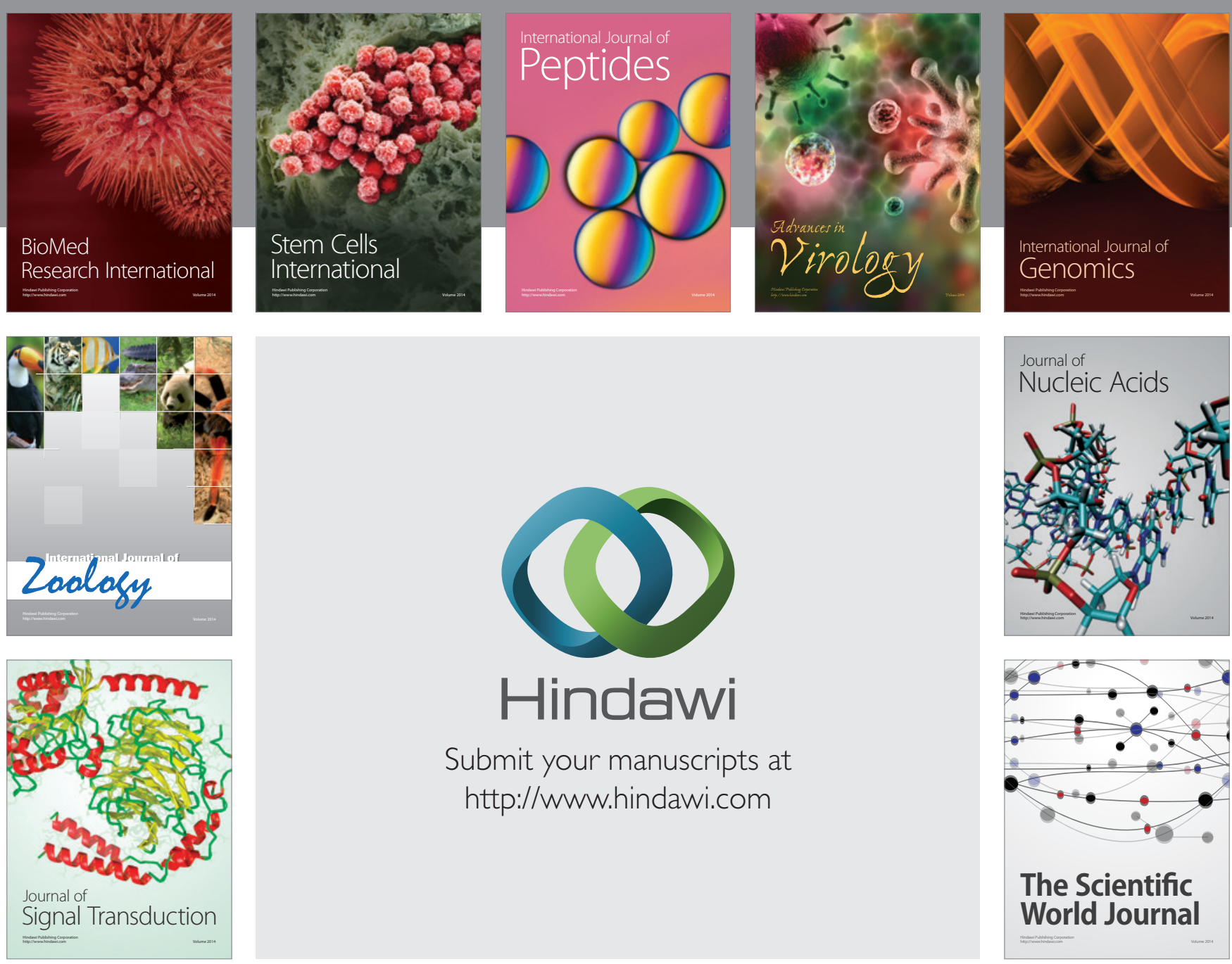

Submit your manuscripts at

http://www.hindawi.com
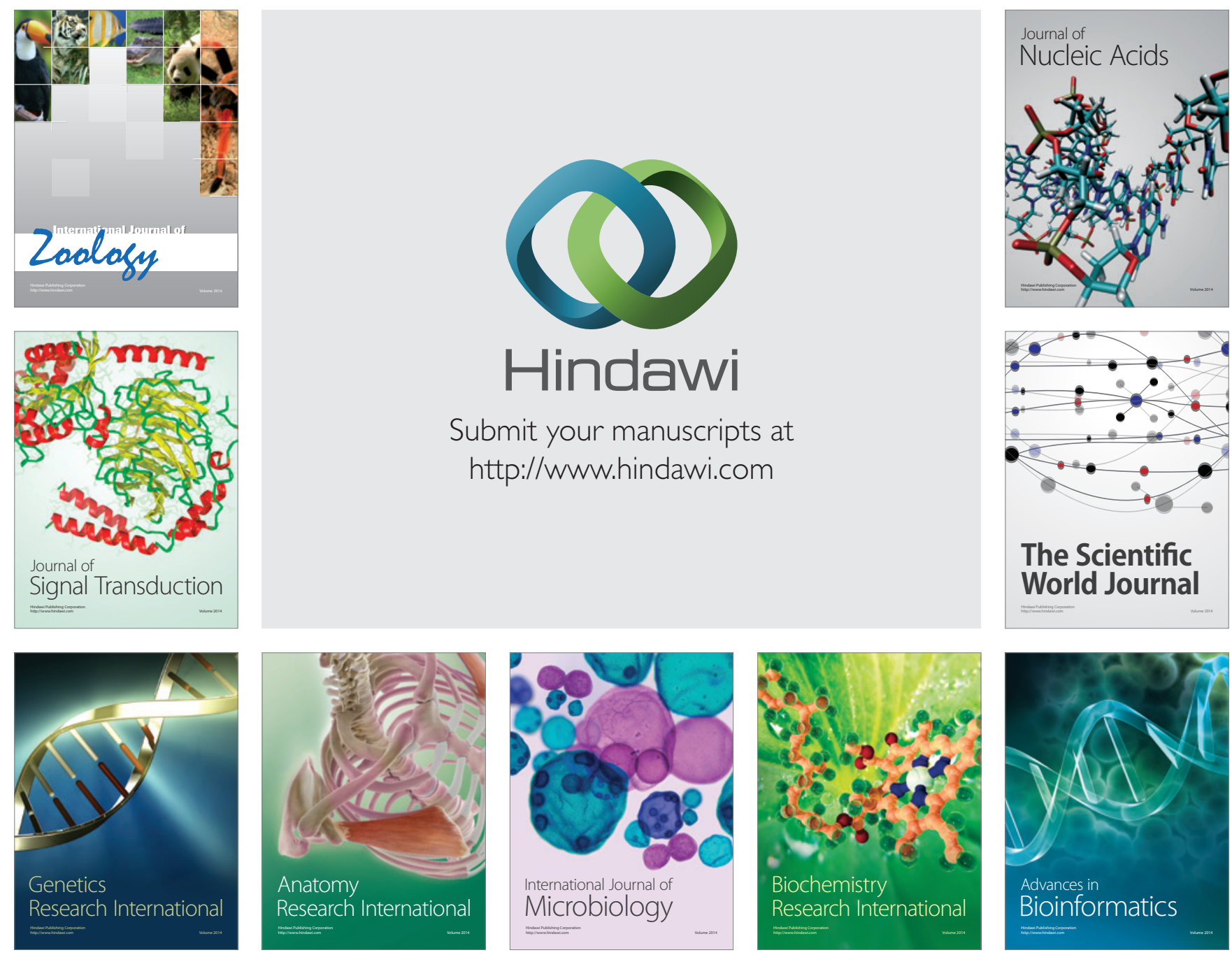

The Scientific World Journal
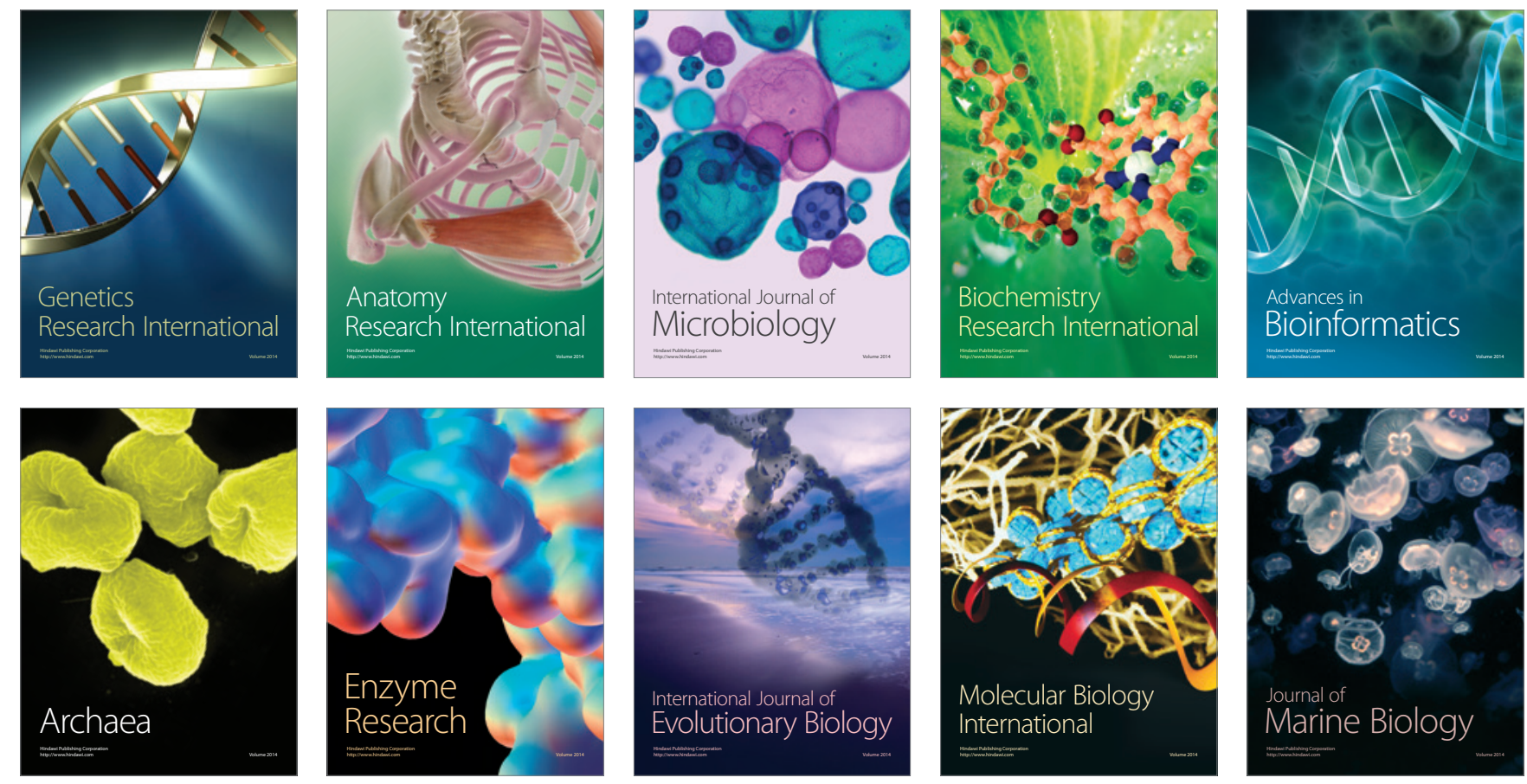